\title{
新潟平野中央部における低沸点有機塩素化合物による地下水污染
}

\author{
川田邦 明*横山列尾 崎 邦 雄*
}

\section{Groundwater Contamination by Volatile Chlorinated Hydrocarbons in a Central Part of the Niigata Plain}

\author{
Kuniaki KAWATA*, Hiromi YOKOYAMA*and Kunio OZAKI*
}

* Niigata Prefectural Research Laboratory for Health and Environment, 314-1, Sowa, Niigata 950-21 Japan

\begin{abstract}
Groundwater contamination with volatile chlorinated hydrocarbons (VCHs) was found in a metalware manufacturing district located in a central part of the Niigata Plain, Niigata, Japan. VCHs detected were trichloroethylene (TCE), tetrachloroethylene (PCE), 1,1,1-trichloroethane (MCF), cis-1, 2-dichloroethylene (cis-DCE) and 1, 1-dichloroethane (1, 1-DCA). VCHs concentrations in groundwater were ranged from $\left\langle 0.001\right.$ to $7.1 \mathrm{mg} \cdot l^{-1}$ for TCE, $\left\langle 0.001 \sim 0.036 \mathrm{mg} \cdot l^{-1}\right.$ for PCE, $\left\langle 0.001 \sim 1.2 \mathrm{mg} \cdot l^{-1}\right.$ for MCF. Concentrations of $c$ is-DCE and 1, 1-DCA were $<0.01 \sim 5.1$ $\mathrm{mg} \cdot l^{-1}$ and $\left\langle 0.01 \sim 0.61 \mathrm{mg} \cdot l^{-1}\right.$, respectively ; cis-DCE and 1, 1-DCA might be produced biodegradedly in soil from TCE and MCF, respectively.

Groundwater in alluvial aquifers was mainly of the carbonate hardness type, while groundwater quality in diluvial aquifers depended on the location. Although the diluvial aquifers were not polluted by VCHs, some of the alluvial aquifers contaminated by VCHs.

Concentrations of TCE and cis-DCE were determined for a year in groundwater from a well of $10 \mathrm{~m}$ depth at a metalware factory using VCHs. The VCHs concentrations in groundwater were varied with the amount of groundwater pumped up from both the investigated well itself and well set around it as well as with the groundwater level.
\end{abstract}

Key words : volatile chlorinated hydrocarbon, groundwater, water quality, contamination, alluvium

\section{1. 緒言}

低沸点有機塩素化合物類 (VCHs)のうち, トリクロ ロエチレン (TCE), テトラクロロエチレン (PCE) 牛 よび1,1,1-トリクロロエタン $(\mathrm{MCF})$ は，金属製品の 脱脂, 洗浄やドライクリーニングの洗浄剤として広く 用いられている。このらち, TCE 拈よび PCE とつい ては発ガン性や変異原性の報告もあり ${ }^{1)}$, 世界保健機 構 (WHO) は飲料水の暫定ガイドラインとしてそれぞ れ $30 \mu \mathrm{g} \cdot l^{-1}$ 捻よび $10 \mu \mathrm{g} \cdot l^{-1}$ と勧告している2。日本に
扔いては，厚生省が水道水の暫定的な水質基準として $\mathrm{TCE}$ で $30 \mu \mathrm{g} \bullet l^{-1}$ 以下, $\mathrm{PCE}$ で $10 \mu \mathrm{g} \bullet l^{-1}$ 以下, $\mathrm{MCF}$ で $300 \mu \mathrm{g} \bullet l^{-1}$ 以下という值 (以下, 暫定基準值之略す) を 示している3)。さらに, 通商産業省 ${ }^{4}$ 揖よび環境庁5) も同 様の排水目標值や管理目標値を示している。交た, TCE と PCE は「指定化学物質」に指定されている6 これらの化合物による地下水污染は, 欧米7) 10)のみ でなく，わが国に扔いても各地で明らかになってきて

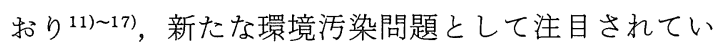
る。著者らは, すでに, 新潟県に拈ける TCEや MCF 
の典型的な使用形態，すなわち，多くの金属製品工場 に扣いて，1社当り年間 $5 \mathrm{t}$ 末満と比較的少量ずつ使 用されているといら特徵を有すると考学られる $\mathrm{A}$ 市 をモデル地区として選び，同市に沶ける地下水中の TCE, PCE, MCF 拈よび cis-1，2-ジクロロエチレン (cis-DCE) による污染実態の概況について報告し た ${ }^{18)}$ 。さらに, 主として中小規模の金属製品工場が多数 立地する新潟平野中央部に位置する地域に括ける TCE およびMCFによる污染概況についても報告 し ${ }^{19)}$ ，新潟県内に扣ける污染の特徵を明らかにした。

本報告では，すでに報告した地域について ${ }^{19)}, \mathrm{TCE}$, PCE 执よび MCFに加えて，これまで報告例の少ない cis-DCE 和よび1，1-ジクロロエタン (1, 1-DCA) に よる地下水污染状況を報告するとともに, 地下水の水 質の調査結果と地層を基に，鉛直方向に拈ける VCHs による污染状況について報告する。さらに，同地区に ある浅井戸に扣いて測定した 1 年間にわたる水質扣よ び VCHs 濃度の変動についてもあわせて報告する。

\section{2. 調査方法}

\section{1 調査地域の概要}

調査地域は, 典型的な沖積平野である新潟平野の中 央部を貫流する信濃川の三角州の州頂付近に位置す
る。同地区の地層は，地表面から，3 層に分類される 沖積層 $\left(\mathrm{A}_{1}, \mathrm{~A}_{2}, \mathrm{~A}_{3}\right.$ 層), さらにその下部の洪積層 $\left(\mathrm{D}_{1}\right.$ 層)からなる ${ }^{20)}$ 。調査地点は, 金属製品工場が多数立地 する市街地または工場団地を中心に選定した。これら の工場では金属製品の脱脂，洗浄用として TCE なた は MCF が使用されている ${ }^{21)}$ 。調査実施期間は1985年 1 月から10月で, 採取地点はFig.1 に示す99地点であ る。揚水された地下水は, 主に工業用水 (冷却用) と して, あるいは冬季間の消雪用や夏季間の冷房用とし て用いられている。

調査地点の $5 ち ，$ 金属製品工場敷地内にある既設の 深さ $10 \mathrm{~m}$ の浅井戸 (以下, \# 1 井戸) について, 1 年間 にわたり毎月 1 回地下水を採取した。この工場では脱 脂, 洗浄用に TCEを使用していたが, 1977年以降, TCE に代わり，MCFを使用している。

工場の操業日には，1 日約 $33 \mathrm{~m}^{3}$ の地下水を\# 1 井戸 から揚水し冷却水として使用していたが，1985年 7 月 に採水してから数日後, 操業工程を変更したのに伴っ て, \#1 井戸の使用を停止したため, 揚水量がほぼゼロ となった。また，7月の下旬から10月の初旬にかけ， \# 1 井戸の北西方向に約 $10 \mathrm{~m}$ 離れた所に位置する井戸 (\#2 井戸)から, 冷房, 冷却用として揚水が行われた。 さらに, 12月の下旬から翌年 3 月にかけては\# 1 井戸の

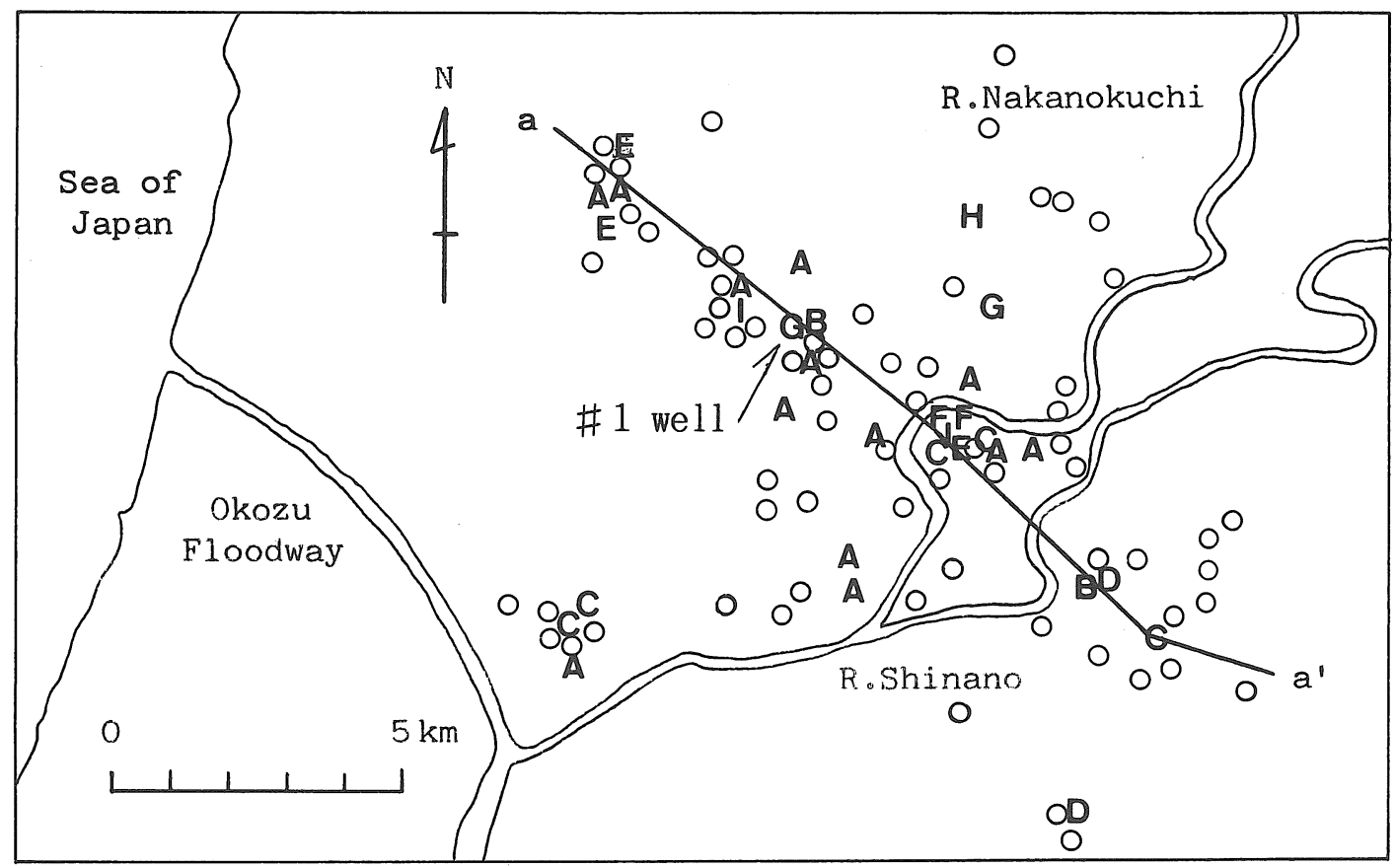

Fig. 1 Sampling wells in a central part of the Niigata Plain.

$\bigcirc$ : not contaminated well. Alphabetical notes show the contaminated wells: A: TCE, B : MCF, C: TCE and cis-DCE, D: MCF and 1, 1-DCA, E: TCE and PCE, F : TCE, PCE and cis-DCE, G: TCE, MCF, cis-DCE and 1, 1-DCA, H : TCE, PCE, MCF and cis-DCE, I: TCE, PCE, MCF, cis-DCE and 1, 1-DCA 
西方向に約 $20 \mathrm{~m}$ 離れた所に位置する井戸 (\# 3 井戸) か ら，消雪用として揚水が行われた。

\section{2 採水方法}

イオン成分分析用試料として，ポリエチレン製瓶に その口まで採水し, 瓶内に空気が残らないように密栓 をした。をた, VCHs分析試料として，スクリュー キャップ付きガラス瓶にその口まで採水し，リン酸を 静かに添加後, 瓶内に空気が残らないように密栓をし た。試料は氷冷して運搬後, 速やかに分析した。

\section{3 実験方法}

\subsection{1 装置}

原子吸光度計：島津製作所製 AA-640-13。イオンク ロマトグラフ：Dionex 社製モデル14。ガスクロマト グラフ：島津製作所製 GC- 6 AM (ECD 付), GC- 7 $\mathrm{A}$ (FID 付)。データ処理装置: 島津製作所製クロマト パック $\mathrm{C}-\mathrm{R} 1 \mathrm{~B}$ 。

\subsection{2 試薬}

TCE, PCE 特よび MCF の標準は，いずれも和光純 薬工業製 $1000 \mathrm{mg} \cdot l^{-1}$ 標準液を，また，cis-DCEは Al一 drich 社製標準品を, 1，1-DCA は東京化成標準品を和 光純薬工業製残留農薬試験用メタノールで適宜希釈し て使用した。その他の試薬はいずれも国産市販品を用 いた。

\subsection{3 分析法}

$\mathrm{Na}^{+}, \mathrm{K}^{+}, \mathrm{Ca}^{2+}, \mathrm{Mg}^{2+}, \mathrm{NH}_{4}{ }^{+}, \mathrm{PO}_{4}{ }^{3-}$ 抢よび全有 機体炭素 (TOC) はいずれも JIS 法で22), $\mathrm{Fe}^{2+}$ は上水

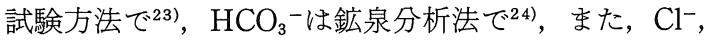
$\mathrm{NO}_{3}$-特よび $\mathrm{SO}_{4}{ }^{2-}$ はイオンクロマトグラフ法で25) 各々分析した。VCHsは, 試料搬入後, 速やかに, TCE, PCE 拈よび MCF はへッドスペース・ガスクロマトグ ラフ（ECD 拈よび FID）法により4),18)，cis-DCE 拈よ び1，1-DCA はヘッドスペース・ガスクロマトグラフ (FID) 法によりそれぞれ分析した。ガスクロマトグラ フ (FID) 分析条件を以下に示す。な抒，定量は正確を 期するために 2 種類の異なるカラムを併用して行っ た。2つの分析条件による定量結果はよく一致した。

カラム：ガラスカラム, $3 \mathrm{~m} \times 3 \mathrm{~mm}$ (i. d.)に $5 \%$ SP-1200 と1.75\%Bentone34で被覆したChromosorb W（AW-DMCS), 60〜80メッシュを充媜したもの, カラム温度: $70^{\circ} \mathrm{C}$, 注入口挹よび検出器温度 : $120^{\circ} \mathrm{C}$, キャリヤーガス: 窒素, $30 \mathrm{~m} l \cdot \mathrm{min}^{-1}$ 。

カラム: ガラスカラム, $2 \mathrm{~m} \times 3 \mathrm{~mm}$ (i.d.) に $25 \%$ TCPで被覆したChromosorb W (AW-DMCS), 60 80メッシュを充媜したもの, カラム温度： $70^{\circ} \mathrm{C}$, 注 入口抢よび検出器温度: $120^{\circ} \mathrm{C}$, キャリヤーガス: 窒 素, $40 \mathrm{~m} l \cdot \mathrm{min}^{-1}$ 。

\section{3 . 結果と考察}

\section{1 地下水中の低沸点有機塩素化合物類の濃度}

全測定地点に扮けるVCHsの濃度の分布をTable 1 に示す。99点中TCEは28地点で, PCEは 6 地点で, MCFは11地点で, cis-DCEは15地点で,また，1,1DCA 5 地点で検出された。

PCE は金属製品工場での使用例は見られず，クリー ニング業等の他の業種で使用されたものと考兄られる が, 使用状況が明確でなく污染と使用工場の関係は不 明であった。

$c i s-\mathrm{DCE}$ 抽よび 1, 1-DCA は，昭和57年度に環境庁 が全国で実施した地下水調査でも，検出率はそれぞれ $9 \%$ 抢よび $2 \%$ と少ないるのの，すで確認されてお り, 最高值はそれぞれ 537 扒よび $175 \mu \mathrm{g} \cdot l^{-1}$ であり, 地 下水中の $c i s-\mathrm{DCE}$ の濃度は TCE や PCE の濃度と高 い相関を示したと報告されている ${ }^{12)}$ 。た, 多摩地区で は cis-DCEが検出された地下水の大部分から TCE が同時に検出されたと報告されている13)。

本調査では，cis-DCEが確認された15地点のすべて でTCEが同時に検出された。1,1-DCA については, 確認された地点は 5 地点と少ないが，すべて MCF が 検出された地点と一致した。

cis-DCEは天然物の抽出等に使用されてはいる $か^{13)}$, 本調査地域では $c i s-D C E の$ 使用は認められず, また，1，1-DCAの使用も認められなかった。そして， TCEが微生物により分解されcis-DCEが生成すると いう報告や26) 28)，MCFが微生物により分解され1,1DCAが生成するといら報告がある ${ }^{29)}$ 。したがって， cis-DCE と1,1-DCA は，それぞれ TCE と MCF の微 生物による分解生成物である可能性も否定できない。

また，TCE濃度に対するcis-DCE濃度の比率は 0.07 ～ 52 の範囲に，また，MCF濃度に対する 1,1 DCA濃度の比率は0.16 0.82の範囲にあり，いずれの

Table 1 Concentration levels of VCHs in groundwater

\begin{tabular}{|c|c|c|c|c|c|c|}
\hline \multirow{2}{*}{\multicolumn{2}{|c|}{$\begin{array}{c}\text { Concentration } \\
\left(\mathrm{mg} \cdot \mathrm{l}^{-1}\right)\end{array}$}} & \multicolumn{5}{|c|}{ Number of wells } \\
\hline & & TCE & PCE & $\mathrm{MCF}$ & cis-DCE & $1,1-\mathrm{DCA}$ \\
\hline & $<0.001$ & 71 & 93 & 88 & & \\
\hline 0.001 & $\begin{array}{l}-\quad 0.003 \\
\end{array}$ & 12 & 3 & 5 & $84^{*}$ & $94^{*}$ \\
\hline 0.003 & $-\quad 0.01$ & 2 & 1 & 0 & & \\
\hline 0.01 & - $\quad 0.03$ & 1 & 1 & 1 & 0 & 1 \\
\hline 0.03 & - $\quad 0.1$ & 2 & 1 & 0 & 0 & 1 \\
\hline 0.1 & $\begin{array}{l}-\quad 0.3 \\
\end{array}$ & 0 & 0 & 2 & 2 & 1 \\
\hline 0.3 & -1 & 2 & 0 & 2 & 5 & 1 \\
\hline 1 & -3 & 5 & 0 & 1 & 5 & 1 \\
\hline 3 & - 10 & 4 & 0 & 0 & 3 & 0 \\
\hline $10<$ & & 0 & 0 & 0 & 0 & 0 \\
\hline
\end{tabular}




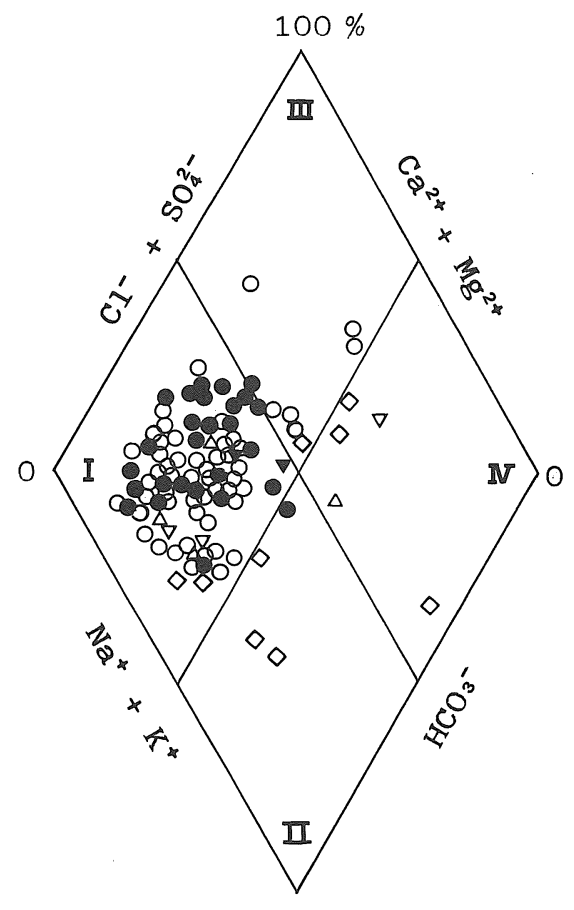

$100 \%$

Fig. 2 Inorganic chemical compositions of groundwater.

$\bigcirc: \mathrm{A}_{1}, \triangle: \mathrm{A}_{2}, \nabla: \mathrm{A}_{3}, \diamond: \mathrm{D}_{1}$. See captions of Fig. 3. I : carbonate hardness, II : carbonate alkali, III : noncarbonate hardness, IV : noncarbonate alkali. Closed symbols show the contaminated wells.
濃度比も地点により差がみられた。この理由として， cis-DCEと1，1-DCAがそれぞれTCEと MCF の微 生物に上る分解生成物であるとすれば，各地点に打け るVCHsの污染を受けてからの期間や土壤中の微生 物に差異があるためにVCHsの分解率が異なること や，地下に打けるTCEとcis-DCE，または MCF と 1,1-DCA との挙動が異なることが考光られた。

\section{2 垂直方向の地下水の水質}

対象とした99地点の地下水の水質についてキーダイ ヤグラムによる分類を行った。その結果, Fig. 2 に 示すように, 地下水の水質はアルカリ土類炭酸塩型 ( I 類), アルカリ炭酸塩型 (II 類), アルカリ土類非炭酸塩 型(III類)扔よびアルカリ非炭酸塩型(IV類)に広く分布 しているものの，大部分はI 類に属していた。これは 対象とした井戸の多くが，アルカリ土類炭酸塩を多く 含む地層から揚水する浅井戸であることに起因するも のと考党られた ${ }^{30)}$ 。

対象地点のうち，井戸の最深部が $\mathrm{A}_{1}, \mathrm{~A}_{2}, \mathrm{~A}_{3}$ 和よび $\mathrm{D}_{1}$ 層に達していると考光られる井戸数は, 各々 80,4 ,

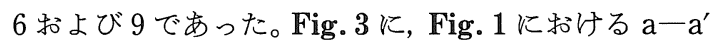
断面図とその付近の井戸を示す。 $\mathrm{A}_{1}$ 層にある井戸から 揚水している地下水は, 大部分が I 類に, 一部がIII類 に属していた。 $\mathrm{A}_{2}, \mathrm{~A}_{3}$ 層に達していると考克られる井 戸から揚水している地下水は, 大部分が I 類に属し, 残る一部がIV類に属していた。したがって， $\mathrm{A}_{1}, \mathrm{~A}_{2}$ 利 よび $\mathrm{A}_{3}$ 層の地下水の水質は明確には区別できなかっ た。また， $\mathrm{D}_{1}$ 層に達していると考学られる井戸から揚 水している地下水は，I～IV類に広く分布しているこ

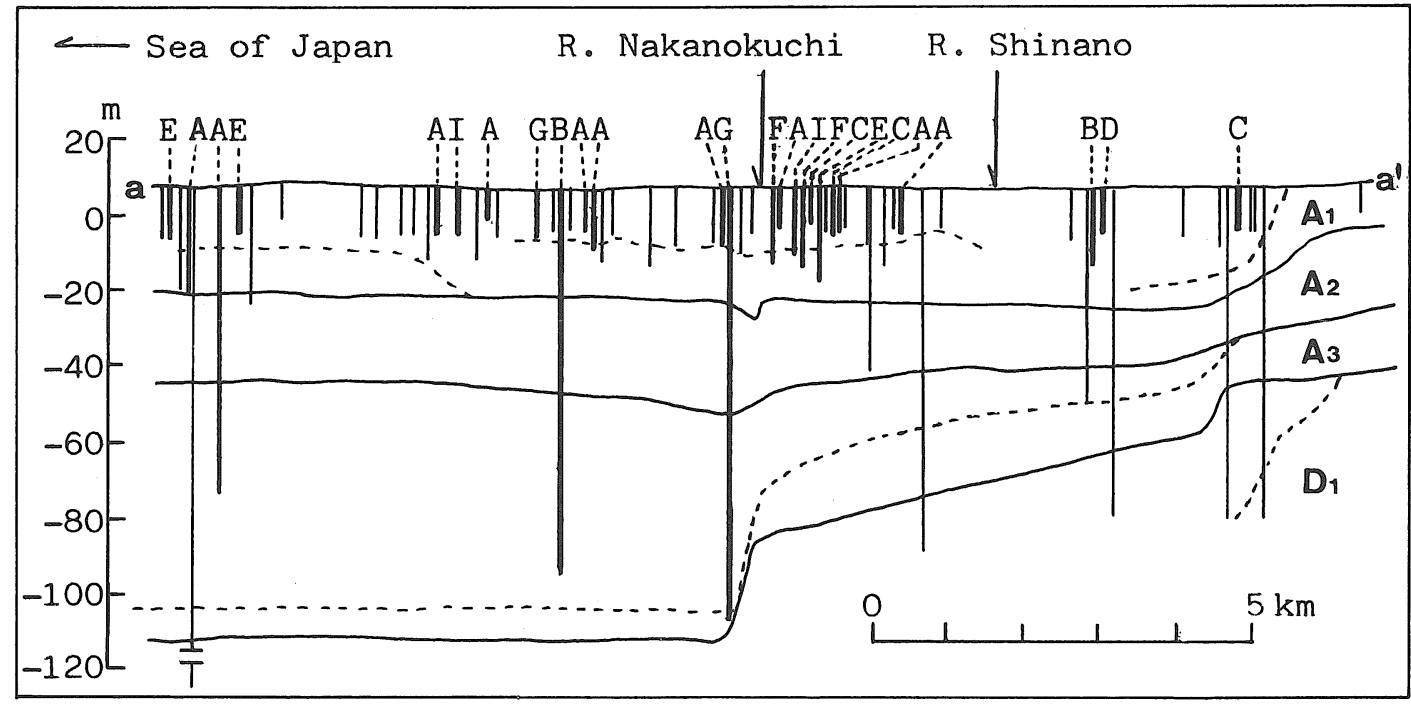

Fig. 3 a-a' Section with location of sampling wells. $A_{1} \sim A_{3}$ : alluvium, $D_{1}$ : diluvium. Alphabetical notes: see caption of Fig. 1. 
とから， $\mathrm{D}_{1}$ 層では水平方向に执いて地域的に水質が異 なる20)ものと考兄られた。

\section{3 垂直方向の污染形態}

VCHsによる污染が確認された地点の地下水は, 井 戸の深さにかかわらずその渒とんどが I 類に属して招 り，III招よびIVに属する地点が各々 1 地点ずつあった が，極めて I 類に近い組成であった。また，污染井戸 の大部分が $\mathrm{A}_{1}$ 層から揚水していた。

$\mathrm{A}_{3}$ 層まで達すると考光られる2つの井戸から採取 した地下水でも污染が認められた。これらの井戸では 複数のストレーナーが設けられていることから, 複数 の帯水層から揚水していると考光られた。本調查結果 からは $\mathrm{A}_{1}, \mathrm{~A}_{2}$ 抢よび $\mathrm{A}_{3}$ にある帯水層の水質は明確に は区別できなかったことから，これらの地点では $\mathrm{A}_{1}$ 層 の帯水層のみが污染されているのか, あるいは污染が $\mathrm{A}_{2}$ 拉よび $\mathrm{A}_{3}$ 層まで達しているのかは判断できなかっ た。これに対し， $D_{1}$ 層に達すると考光られる井戸から 採取した地下水には污染が認められなかったことか ら，污染は $\mathrm{D}_{1}$ 層には達していないものと考觉られた。

したがって，VCHsによる污染は最も浅い $\mathrm{A}_{1}$ 層を 中心に進行して括り， $\mathrm{A}_{2}$ 抒よび $\mathrm{A}_{3}$ 層にまで達してい る可能性もあるが, $\mathrm{A}_{1} \sim \mathrm{A}_{3}$ 層の下部に位置する $\mathrm{D}_{1}$ 層 には達していないと考学られた。

\section{4 金属製品工場内の浅井戸における通年調査}

金属製品工場敷地内に設置されている\#1井戸に拉 ける 1 年間にわたる調査結果のらち水質の変動を Fig. 4 亿示す。測定した 6 種の陽イオンの総量と 5 種 の陰イオンの総量とはよく一致した。また, $\mathrm{Fe}^{2+} か ゙$ $0.1 \sim 1.9 \mathrm{epm}$ (平均 $1.2 \mathrm{epm}$ ) と比較的高濃度で含まれ ていた。これは，本調査対象地点では地質的に鉄が豊 富なため ${ }^{11)}$ と考兄られた。そして，TOC が比較的高い ことから有機物を比較的多く含有していることがわ かった。さらに, $\mathrm{NH}_{4}{ }^{+}$も比較的多く, 極微量ではある が $\mathrm{PO}_{4}{ }^{3-}$ も含をれていたことから，人為的污染を受け ていることが示された。そして，年間を通じて水質は I 類に属していた。主要イオン成分濃度は， 7 月から 10 月怙よび 12 月に比較的低く, これに伴って電気電導 度も低值であった。

Fig. 5 に\# 1 井戸付近の地下水位と降水量の年間変 動を示す。地下水位は冬季に下がり，春季から夏季に かけて上昇し, また, 夏季から秋季に和いてやや下降 する。このような地下水位の年間変動は, 必ずしも降 水量に伴って変化するわけではないが, 新潟県内の積 雪地域に括いて広く認められている ${ }^{32)}$ 。\#1井戸では地 下水位の測定はできなかったが，夏季から秋季に拉い ては, 主要イオン成分濃度や電気電導度が低值であり, しかも，アルカリ土類金属の濃度に対するアルカリ金

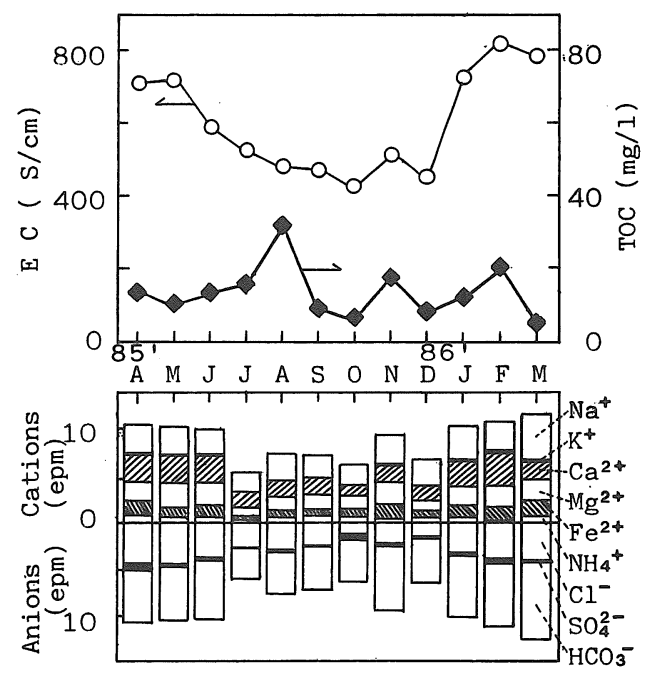

Fig. 4 Variations of quality of groundwater from a well of $10 \mathrm{~m}$ depth located at a metalware factory (\# 1 well).

EC $(\bigcirc)$ : electric conductivity, TOC $(\diamond)$ : total organic carbon

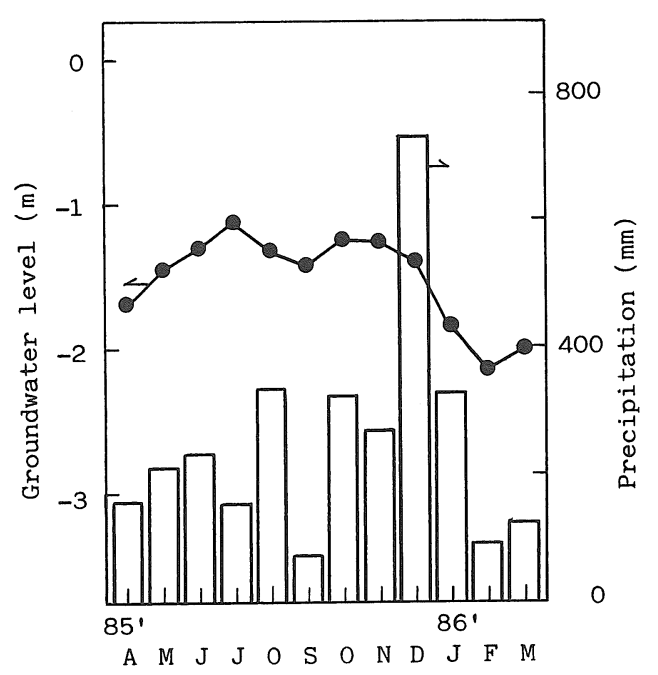

Fig. 5 Variations of groundwater level and precipitation.

属の濃度の比が比較的低值であるなど，地表水に近い 組成であったことから，この時期には降雨等により地 下水位は上昇して打り, 逆に, 冬期間には地下水位が 下降していたと考兄られた。すなわち，\#1井戸に沶い ても地下水位はFig.5に示すよらな変動をしたもの と推定された。

VCHs の濃度変動を Fig. 6 に示す。VCHs の濃度は 8〜10月に激減し，11〜 3 月にかけて再び比較的高濃 度で検出された。地下水中の TCE 濃度の変動を地下 


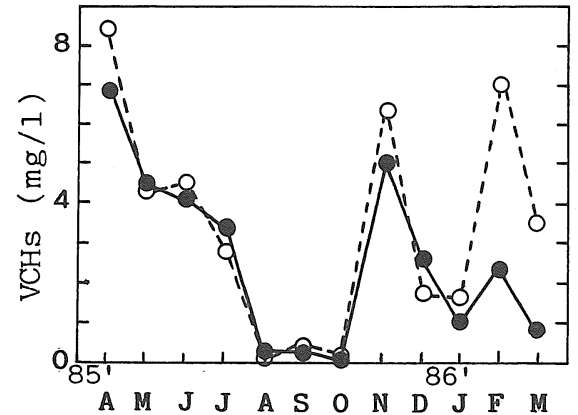

Fig. 6 Variations of $\mathrm{VCH}$ concentrations in groundwater from the \# 1 well.

: TCE, $\bigcirc$ : $c$ is-DCE

水位に着目し, 水位が上昇すると TCE 濃度が減少す る例 ${ }^{33)}$ と逆に増加する例 ${ }^{34)}$ が報告されている。

\# 1 井戸に拈ける VCHs 濃度の季節変動について は, 水質の変動から, 概水地下水位が上昇すると VCHs 濃度が減少する傾向は見られたが, 詳細にみる と両者の変動は必ずしも一致していなかった。

著者らは19)，年間を通して使用されている井戸から 揚水された地下水中の TCE なは MCF 濃度の変動 は小さいのに対し, 一定期間のみ使用されている井戸 では，使用された期間に扣ける TCE 等の濃度が高い 傾向があったことから, 地下水中の TCE 等の濃度は 井戸の使用状況の影響を強く受けている可能性が高い ことを報告した。

Fig. 6 に示すように, \#1 井戸を使用していた 4 〜 月にかけては, 水位の上昇に伴い VCHs 濃度は概小減 少傾向にあった。しかし, \#1 井戸の使用停止後につい ては，\#2 井戸が使用されていた $8 \sim 10$ 月にはVCHs 濃度は激減した。そして，\#3 井戸が使用されていた 12〜3月にかけてはVCHs 濃度は 4 月月の間と 8 〜10月の間の中間の濃度レベルにあった。このように, \#1井戸和よびその周辺に位置する井戸の使用状況が 変化した時期と, VCHs の濃度が大きく変動した時期 とはよく一致した。VCHs 濃度の変動に対する各井戸 の厳密な役割の解明は困難であるが, \# 1 井戸扎よびそ の周辺の井戸からの揚水量の変化に伴い, \# 1 井戸周辺 の地下水の局地的な流れの速度や方向に変化が生じた ことが考えられた。すなわち，地下水中の VCHsの濃 度は, 地下水位の変化のみに影響されるのではなく, 対象とする井戸执よびその周辺にある井戸の揚水量の 変化によっても大きく変動すると考えられた。

\section{4. 結論}

金属製品の脱脂，洗浄にVCHsを使用す主金属製品
工場が多数立地する新潟平野の中央部に位置する地域 に扣いて，TCE，PCE，MCF，cis-DCE扣よび1,1DCA による地下水污染が確認された。

cis-DCE は TCEの，また，1,1-DCA は MCF のそ れぞれ微生物による分解生成物と考えられた。

また，地下水の水質は，沖積層では大部分がアルカ リ土類炭酸塩型であり, 洪積層では地域により異なっ ていた。そして，VCHsによる活染は最も浅い $A_{1}$ 層を 中心に進行したが， $\mathrm{A}_{1} \sim \mathrm{A}_{3}$ 層の下部に位置する $\mathrm{D}_{1}$ 層 には達していないと考えられた。

さらに，金属製品工場の浅井戸(深さ $10 \mathrm{~m}$ )における 地下水の通年調査から, 水質は年間を通してアルカリ 土類炭酸塩型であること, 主要イオン濃度, 電気電導 度执よび VCHs の濃度は, 夏季に低く冬季に高い傾向 が認められ，その原因として，地下水位や，調査井戸 またはその周辺にある井戸の使用状況の変化の影響と 考学られることがわかった。

（概要は，第21回水質污濁学会，1987年 3 月，東京で講 演)。 （原稿受理 昭和64年 1 月 4 日）

\section{引用 文 献}

1) 安藤正典(1983)有害物質による地下水污染実態調査一文献 調査一(昭和 57 年度環境庁委託業務結果報告書), $103 \mathrm{pp}$., 日本水 質污濁研究協会.

2) 日本水道協会抄録委員会 (1985)WHO 飲料水水質ガイドラ イン ( I ) -勧告-, 水道協会雑誌, 54, 34-91.

3 ) 厚生省 (1984)水道水中のトリクロロエチレン, テトラクロロ エチレン及び $1,1,1$-トリクロロエタン対策について, 環水 第15号（昭和59年 2 月 18 日).

4) 通商産業省 (1984)トリクロロエチレン, テトラクロロエチレ ン及び $1,1,1$-トリクロロエタンに係る暫定排出濃度目標の 設定について，59立局第504号（昭和59年 8 月 22 日）.

5 ) 環境庁(1984)トリクロロエチレン等の排出に係る暫定指導 指針の設定について，環水管第 127 号，環水規第 148 号（昭和59 年 8 月 22 日).

6 ) 厚生省, 通商産業省 (1987)告示第 10 号 (昭和 62 年 5 月 25 日).

7) Trouwborst, T. (1981) Groundwater pollution by volatile halogenated hydrocarbons; sources of pollution and methods to estimate their relevance, The Science of Total Environment, 21, 41-46.

8 ) Page, G.W. (1981) Comparison of groundwater and surface water for patterns and levels of contamination by toxic substances, Environmental Science \& Technology, 15, 1475-1481.

9) Clark, C.S., C.R. Meyer, P.S. Gartside, V.A. Majeti,B. Specker, W.P. Balistreri and V.J. Elia (1982) An environmental health survey of drinking water contamination by leachate from a pesticide waste dump in Hardeman County, Tennessee, Archives of Environmental Health, 37,9-18.

10) Gruber, P. (1983) Evaluation of ground-water contamination associated with the use of organic solvents at Romansville, Pennsylvania, Proceeding of 3rd National Sympo- 
sium of Aquifer Restor Ground-Water Monitaling 1983. p. 69-75.

11）佐谷戸安好, 中室克彦, 安藤正典, 石塚美恵子, 佐野仁, 頭 本藤雄(1983)多摩川水系地下水中の低沸点有機塩素化合物の 分布と塩素化反応生成物の消長について, 水質污濁研究, 6 , $39-45$.

12) 中杉修身 (1984) 有機塩素化合物による地下水污染の実態, 環 境研究, 52, 125-135.

13）矢口久美子, 大橋則雄, 渡辺学, 関山登, 中村弘, 坂井千三 (1984)多摩地区地下水中の塩素系有機溶剤に関する調査, 東京 都立衛生研究所研究年報, 35, 363-370。

14）古賀輝彦(1985)トリクロロエチレン等の污染経路と深井戸 改修工事一三鷹市に怙ける事例一, 水道協会雑誌, 54, 7-16.

15）玉川勝美, 大金由夫, 相原良之, 広島紀以子, 加藤恵, 三島 靖子, 関敏彦, 角田行 (1985) 仙台市に和ける低沸点有機塩素化 合物による地下水污染事例(第 1 報), 衛生化学, 31, 214-219.

16) 神野健二, 上田年比古, 粐井和郎, 大石秀人, 安田裕 (1986) テトラクロロエチレンによる地下水污染についての水文地質 学的考察, 日本地下水学会誌, 28, 113-125.

17）田中克彦, 䉆山享志, 杉山英俊, 伏脇裕一, 橋本茂, 草野恵 美子(1986)神奈川県内に打ける地下水, 河川水及び工場排水の 有機塩素系溶剤に関する調査, 水質污濁研究, 9, 798-805.

18）川田邦明, 尾崎邦雄, 横山ひろ及, 黒崎裕人 (1987)金属製品 製造工場からの有機塩素化合物類による地下水污染, 用水と廃 水, 29, 221-226.

19）川田邦明, 尾崎邦雄, 横山ひろみ, 高橋達男, 須藤透(1988) 金属製品製造工業地域に打ける低沸点有機塩素化合物による 地下水污染, 生態化学, 9(3), 3-7.

20) Iwanaga, S. and T. Ishibashi (1977) Aquifer and buried terrace in the central part of the Niigata plain. Engineering Geology, 18, 117-124.

21）新潟県環境保健部(1985)新潟県に拈けるトリクロロチレン 等使用実態調查結果 (昭和59年度).
22）日本規格協会(1981)工場排水試験法 JIS K0102.

23）日本水道協会(1985) 上水試験法.

24）鉱泉工学会 (1978)鉱泉分析法指針(改訂).

25）松本光弘, 板野龍光 (1984)イオンクロマトグラフィーによる 雨水中のイオン成分の検討, 大気污染学会誌, 19, 247-254.

26) Parsons, F., P.R. Wood and J. DeMarco (1984) Transformations of tetrachloroethene and trichloroethene in microcosms and groundwater, Journal of American Water Works Association, 76 (2) ,56-59.

27) Kleopfer, R.D., D.M. Easley, B.B. Haas, Jr., T.G. Deihl, D. E. Jackson and C.J. Wurrey (1985) Anaerobic degradation of trichloroethylene in soil, Environmental Science \& Technology, 19, 277-280.

28) Vogel, T.M. and P.L. MacCarty (1985) Biotransformation of tetrachloroethylene to trichloroethylene, dichloroethylene, vinyl chloride and carbon dioxide under methanogenic conditions, Applied and Environmental Microbiology, 49, 1080-1083.

29) Parsons, F. and G.B. Lage (1985) Chlorinated organics in simulated groundwater environments, Journal of American Water Works Association, 77 (5), 52-59.

30) 山本荘毅 (1983) 新版地下水調査法, 379-381, 古今書院, 東京.

31）新潟県(1977)新潟県地質図説明書, p.380.

32）新潟県環境保健部公害対策課 (1987) 新潟平野の地盤沈下, 長 岡地区の地盤沈下 (11), 南魚沼地区の地盤沈下 (11), 上越地区 の地盤沈下 (16).

33）中辻啓二(1986)有機塩素化合物による地下水污染の時間的, 空間的広がり, 合成有機化合物による地下水污染機構の解明に 関する基礎的研究, 文部省環境科学特別研究報告書 B-293R12-14, 101-112.

34）中杉修身 (1986)地下水污染の実態とその類型的整理, 合成有 機化合物による地下水污染機構の解明に関する基礎的研究, 文 部省環境科学特別研究報告書 B-293-R12-14, 19-27. 


\section{論文要旨}

\section{流動床による強酸性含鉄排水の処理に関する研究}

海田 輝之* Valentin Nenov** 大村 達夫* 相沢 治郎* 大沼 正郎*

* 岩手大学工学部土木工学科 $* *$ University of Chemical Technology, Burgus, Bulgaria

〈水質污濁研究 Vol.12 No.5（1989） pp.297～305〉

強酸性で高濃度の 2 価鉄を含む排水を処理する場合，鉄酸化細菌で 2 価鉄を酸化し，その後中和する方法が 行われている。本研究ではこの第 1 段階の酸化を行う際, 流動床を用いた場合についてその処理特性を検討し た。

まず，回分実験で 2 価鉄酸化活性に及ぼす DO，初期 2 価鉄濃度の影響について検討し，共に Monod 型で表 されることが分かった。ぬた，鉄酸化細菌の付着担体としては，本実験の範囲内ではイオン交換樹脂が最適で あった。次に流動床を用いて 2 価鉄の連続酸化実験を行った。その結果, HRT が20分程度で $90 \%$ 以上の酸化率 を得ることができた。さらに，2 価鉄の担体への拡散と担体内での消費を考慮して流動床内での 2 価鉄濃度の 変化をモデル化し，定常時について流出 2 価鉄濃度を表す式を誘導した。この式により回分実験で得られた速 度式を用いれば，実験時の流出濃度を概ね表し得た。

\section{新潟平野中央部における低沸点有機塩素化合物による地下水污染}

川田 邦明* 横山ひろ久* 尾崎 邦雄*

* 新潟県衛生公害研究所

〈水質污濁研究 Vol.12 No.5（1989） pp.306 312〉

新潟平野中央部の金属製品工場が多数立地する地域でトリクロロエチレン, テトラクロロエチレン, 1, 1, 1-ト

リクロロエタン，cis-1，2-ジクロロエチレン抢よび1，1-ジクロロエタンによる地下水污染を確認した。 cis-1，2-ジクロロエチレンと 1, 1-ジクロロエタンは, 各々, トリクロロエチレンと $1,1,1$-トリクロロ エタンの分解生成物と考光られた。をた, この地域の地下水の水質は, 沖積層では大部分がアルカリ土類炭酸 塩型であり，洪積層では地域により異なっていた。そして，低沸点有機塩素化合物による污染は沖積層のうち 最も浅い層を中心に進行したが，洪積層には達していないと考光られた。

さらに，金属製品工場にある深さ $10 \mathrm{~m}$ の井戸に拈ける地下水の通年調査から，低沸点有機塩素化合物の濃度 は地下水位や，調查井戸またはその周辺にある井戸の使用状況の変化による影響を受けると考学られた。 